\title{
PREVODI ROMANA ALBE DE SESPEDES NA SRPSKOM I HRVATSKOM GOVORNOM PODRUČJU
}

Cilj rada je osvijetliti prevode romana italijansko-kubanske književnice, intelektualke i novinarke, Albe de Sespedes (Alba de Céspedes), na srpskom i na hrvatskom govornom području. Pri osvrtu na prevode, pozabavićemo se saradnjom Albe de Sespedes sa jugoslovenskim prevodiocima i izdavačima. Kroz analizu prevoda tri romana, između ostalog, na primjerima pojedinih segmenata, fokusiraćemo i neke aspekte prevođenja. Jedan od ciljeva rada je i da ukaže na eventualnu potrebu za novim prevodima djela Albe de Sespedes koji bi savremenim čitaocima na srpskom i hrvatskom govornom području zasigurno približili bogat i raznorodan opus ove svestrane autorke.

Ključne riječi: Alba de Sespedes, italijanska književnost XX vijeka, $\mathrm{Ne}$ ssuno torna indietro, Dalla parte di lei, Quaderno proibito, prevod

Pisati o prevodima djela italijanskih književnika na srpskom i na hrvatskom govornom području znači dotaknuti se nedovoljno obrađene teme koja je na neki način ostala na margini istraživanja. I pored toga što je nauka o prevođenju već duže vrijeme afirmisana kao naučna disciplina, prevodima sa italijanskog na srpski i na hrvatski jezik do sada se nije posvećivala pažnja kakvu oni zaslužuju, posebno kada se radi o djelima autora koji ne zauzimaju vođeće mjesto u književnom kanonu. Stoga je ovaj rad nastao sa ciljem da osvijelti prevode romana Albe de Sespedes (Alba de Céspedes, 1911-1997), donoseći na taj način jednu novu perspektivu u istraživanju stvaralaštva istaknute predstavnice italijanskog književnog i kulturnog života prošlog vijeka, koja je svojim aktivnostima dala značajan doprinos obnovi i razvoju društva nakon Drugog svjetskog rata. Iako je djelo ove angažovane intelektualke, književnice i novinarke, nepravedno

\footnotetext{
* $\quad$ zorana.kovacevic@flf.unibl.org
} 
zapostavljene u kritičkoj i čitalačkoj recepciji sve do početka ovog vijeka ${ }^{1}$, imalo velikog odjeka van granica Italije, ono je ostalo skoro nepoznato na tlu bivše Jugoslavije i na Balkanu uopšte. S obzirom na to, rad će se, nakon preliminarnih razmatranja opšteg karaktera, ključnih za upoznavanje sa spisateljicom, fokusiranih prvenstveno na recepciju njenih djela u svijetu, baviti prevodima tri romana Albe de Sespedes na srpskom i hrvatskom govornom području. Nakon što se osvrnemo na postojeće prevode romana Nessuno torna indietro (1938), Dalla parte di lei (1949) i Quaderno proibito (1952) ukazujući na njihove opšte karakteristike, na primjerima pojedinih segmenata osvijetlićemo i neke aspekte prevođenja, ograničavajući se pritom na uži korpus jer bi svaki drugi pristup premašio okvire jednog rada ovog tipa.

\section{1. „Ako moju knjigu razumiju u Japanu, to je znak da je univerzalna"62}

Jedna od karakteristika italijanske književnosti XX vijeka je njen kosmopolitski karakter koji se, između ostalog, ogleda u konstantnoj težnji književnika da kroz putovanja i kulturnu razmjenu obogate svoje horizonte, a samim tim i djela koja često svjedoče o novostečenim iskustvima. Laura di Nikola u radu Il canone inverso. I classici italiani del Novecento all'estero, fokusiranim na prisustvo italijanskih klasika XX vijeka u inostranstvu, ističe da je još jedan bitan aspekt, usko vezan za kosmopolitizam, sklonost i interes pisaca za učenje stranih jezika: "un poliglottismo diffuso, e un'attenzione di scavo verso la parola che si riflettono in una consapevolezza pratica e teorica del mestiere del tradurre" (Di Nicola, 2013: 69). Sto-

1 Kako na vrijednost književnih ostvarenja Albe de Sespedes, tako na njen angažman na kulturnom i društvenom polju podsjetila nas je na prvom mjestu Marina Cankan (Marina Zancan), autorka istaknutih radova iz oblasti ženske književnosti. Zahvaljujući publikacijama iz 2001. i 2005. godine, priređenih uz pomoć najbližih saradnica, Marina Cankan je dala podstrek za dalja istraživanja o književnici. Od objavljivanja radova Marine Cankan pa sve do danas, nizali su se različiti povodi za studije o Albi de Sespedes koji su rezultirali objavljivanjem velikog broja radova, zbornika i monografija, napisanih ne samo iz pera italijanskih, nego i drugih evropskih i neevropskih stručnjaka. Za više detalja o publikacijama Marine Cankan upućujem na bibliografiju.

Naslov paragrafa preuzet je iz intervjua Pjere Karoli (Carroli, 1993: 131-194) sa Albom de Sespedes vođenom u Parizu u periodu od 19. do 29 marta 1990. godine. Intervju je objavljen kao zaseban dodatak u sklopu monografije Esperienza e narrazione nella scrittura di Alba de Céspedes. 
ga italijanska književnost prošlog vijeka obiluje imenima istaknutih autora poput Pavezea, Montalea, Kalvina, Prima Levija, Fauste Čalente i mnogih drugih koji su bili pravi posrednici između kultura i prevodioci.

Među italijanskim književnicima i intelektualcima pomenutog perioda koji se svrstavaju u red kosmopolita i poliglota izdvaja se nesumnjivo Alba de Sespedes, predodređena da razvije ljubav za strane jezike i kulture prvenstveno zbog svog porijekla i odgoja. Rođena u Rimu od majke Italijanke i oca diplomate kubanskog porijekla ${ }^{4}$, ova autorka će, pored rodnog grada u kome provodi najveći dio života i gdje se afirmiše i stasava kao književnica i novinarka, provesti u Parizu posljednje decenije života opredjelivši se pritom za pisanje na francuskom jeziku ${ }^{4} \mathrm{Na}$ ova dva grada, nezaobilazne tačke intelektualnog i životnog itinerera Albe de Sespedes, nadovezuje se i Kuba kojoj se književnica konstantno vraćala, kako u mislima, tako i za vrijeme svojih čestih i dugih putovanja ${ }^{5}$. Španski i francuski jezik koje je odlično poznavala, te njemački i engleski kojima se takođe služila, uz maternji jezik tvore višejezičnost Albe de Sespedes. Bogata lična biblioteka književnice koju sačinjava 5630 dokumenata, među

3 Otac Albe de Sespedes, Karlos Manuel de Sespedes i de Kesada (Carlos Manuel de Céspedes y de Quesada), kubanskog porijekla, proveo je niz godina u diplomatskoj službi kao ambasador Kube u Rimu. Albin djed, Karlos Manuel de Sespedes i del Kastiljo (Carlos Manuel de Céspedes y del Castillo), 1891. godine je bio izabran za prvog predsjednika Republike Kube.

4 Krajem šezdesetih godina, razočarana društveno-političkom situacijom u Italiji, Alba de Sespedes se povlači iz italijanskog kulturnog i književnog života, te se seli u Pariz gdje je i preminula. 1973. godine u Parizu objavljuje roman napisan na francuskom jeziku Sans autre lieu que la nuit. Tri godine kasnije roman izlazi u Italiji pod naslovom Nel buio della notte, u prevodu same književnice. Pored pomenutog romana, Alba de Sespedes je na francuskom jeziku napisala i zbirku pjesama Chansons des files de mai (1968), objavljenu u Italiji 1970. godine i naslovljenu Le ragazze di maggio.

5 O neraskidivoj vezi sa Kubom svjedoči, između ostalog, i sljedeći odlomak iz posljednjeg nedovršenog romana Con grande amore, posvećenog upravo očevoj rodnoj zemlji: ,[...] L'Italia è il Paese dove sono nata [...] il Paese dove si parla la lingua in cui scrivo, poiché sono innegabilmente una scrittrice italiana... E la Francia è il Paese dove preferisco abitare, dove lavoro meglio, per la discrezione, il riserbo proprio al suo popolo, Parigi dove gli scrittori mi hanno accolta come se fossi da sempre una di loro... Ma Cuba, Cuba è la mia patria [...], farei qualunque cosa per l'Italia, in favore dell'Italia, e verso la Francia sarò sempre grata, leale; ma solo per Cuba - per quello che Cuba è oggi - sarei pronta a morire" (de Céspedes, 2011: 1592). 
kojima su zastupljene knjige, časopisi i razne brošure i na osnovu koje je moguće odrediti njene kulturne i književne afinitete, obiluje knjigama na raznim jezicima, što dokazuje da je Alba de Sespedes imala običaj da čita djela u originalu. Međutim, uprkos činjenici da posjeduje znatan broj knjiga napisanih na stranim jezicima, Alba de Sespedes, svestrana intelektualka, bila je svjesna kako značaja prevoda i uloge koju oni igraju za afirmacije književnih djela i njihovih autora u stranim kulturama, tako i kompleksnosti samog prevodilačkog poduhvata.

Pri osvrtu na prevode djela Albe de Sespedes neizbježno je dotaknuti se lične prepiske sa prevodiocima koju je književnica vodila na nekoliko jezika ${ }^{6}$. Pored prepiske sa izdavačima, čitaocima i drugim književnicima, pisma koja je Alba de Sespedes redovno upućivala prevodiocima u cijelom svijetu, svrstavaju se u najzanimljiviji materijal iz arhiva autorke ${ }^{7}$. S obzirom na to da Alba de Sespedes za razliku od mnogih njenih savremenika nije imala književne agente, izuzev kratke saradnje sa Francuskinjom Odet Arno (Odette Arnaud) tokom 1967. godine, sama je predano pratila svaku fazu cirkulisanja svojih knjiga po svijetu. Osim toga, ova italijanska književnica je nerijetko prilagođavala stil i dužinu svojih romana kako bi olakšala posao prevodiocima i učinila štivo pristupačnijim i bližim čitaocima drugih zemalja. Da bi ostala dosljedna u namjeri da prati izdanja svojih djela na stranim jezicima, prevashodno na engleskom i francuskom, Alba de Sespedes je često intervenisala neposredno nakon njihovog objavljivanja. Uključivanje Albe de Sespedes u proces prevođenja je ponekad rezultiralo revizijom i brojnim korekcijama od strane same književnice što se najbolje vidi na primjeru prevoda romana Dalla parte di

$6 \quad$ Najveći broj pisama iz lične prepiske je na italijanskom i na francuskom jeziku. Kada su u pitanju imena samih prevodilaca, česta su pisma upućena Žulijet Bertran (Juliette Bertrand), Santijagu Nadalu (Santiago Nadal), a predanjači prepiska sa Karin de Laval (Karin de Laval) koja je svojim prevodima doprinijela afirmaciji Albe de Sespedes u Švedskoj.

7 Lični arhiv Albe de Sespedes, zajedno sa biblitekom, sve do smrti književnice se nalazio u njenoj kući u Parizu da bi 1997. godine bio povjeren Marini Cankan (Marina Zancan) i Anariti Butafuoko (Annarita Buttafuoco). 2009. godine postao je sastavni dio fondacije Mondadori (Fondazione Mondadori) u Milanu. U sklopu arhiva nalazi se sljedeća građa: Documenti personali e sulla famiglia (1901-1997), Corrispondenza personale e professionale (1910-1997), Scritti (1918-1997), “Mercurio" (1943-1949), Ritagli stampa (1926-1997), Fotografie (1880-1995), Testi inviati ad Alba de Céspedes (1940-1994). 
lei na engleski jezik. Roman je objavljen u Italiji 1949. godine za vrijeme autorkinog boravka u Vašingtonu, a već 1950. godine izlazi njegov prevod na engleski jezik prilagođen američkim čitaocima. Iz pisma italijanskom izdavaču Albertu Mondadoriju, napisanog 11. jula iste godine, saznajemo da je Alba de Sespedes intenzivno radila na reviziji prevoda Fransis Frini (Frances Frenaye) jer je po njenom mišljenju ovaj prevod djela, iako savršen, bio preobiman za čitaoce ovog govornog područja ${ }^{8}$. Dakle, revizija se prvenstveno sastojala od izostavljanja pojedinih djelova obimnog romana Dalla parte di lei u cilju da se primaocu prevoda ovo djelo što više prilagodi. Tako je redukovana ,američka verzija“ pomenutog romana u nekim slučajevima poslužila spisateljici kao osnova za prevode na druge jezike.

Osim prepiske sa prevodiocima i izdavačima u ličnom arhivu Albe de Sespedes se nalazi drugi dragocjen materijal zahvaljući kojem je moguće stvoriti jasnu sliku o prisustvu Albe de Sespedes u svijetu. Između ostalog, građa ovog arhiva obiluje spiskovima i preglednim tabelama koje je književnica ispisivala rukom ili na pisaćoj mašini, a odnose se na prevode njenih djela grupisanih prema državama ili po naslovima romana. Na osnovu ovog materijala moguće je zaključiti da su se u inostranstvu prvenstveno prevodili romani Albe de Sespedes, dok su njene zbirke propovijedaka i poezija malo poznate stranim čitaocima. Ova spisateljica je prevođena u kontinuitetu na 24 jezika od 1939. godine pa sve do 1985. godine. Kako ističe Laura di Nikola, prisustvo i prevođenje Albe de Sespedes u inostranstvu je trajalo sve dok je ona sama pomno pratila ,putovanje“ svojih knjiga po svijetu, a naporedo sa udaljavanjem iz svijeta književnosti iščeznula su i njena djela: ,[...] una presenza forte di de Céspedes all'estero che si è protratta, come ho detto, solo fino a quando lei ha viaggiato insieme ai suoi libri: quando l'autrice esce dal mondo letterario scompaiono anche le sue opere che lei stessa aveva tenacemente seguito, promosso, accompagnato in ogni singola fase" (Di Nicola, 2013: 73). Nakon 1985. godine javlja se poneki sporadični prevod romana autorke od kojih su neki neautorizovani, kao na primjer prevod romana La bambolona u Šri Lanki iz 2003. godine ili prevod romana Quaderno proibito objavljen u Albaniji 2007. godine9.

8 Za više detalja o ovom pismu pogledati pogovor romanu Dalla parte di lei (Di Nicola, 2011: 1641).

9 Za više podataka o prevodima djela Albe de Sespedes upućujem na rad Laure di Nikola Il canone inverso. I classici italiani del Novecento all'estero. 


\section{Alba de Sespedes na srpskom i hrvatskom govornom području}

Raznorodno i bogato djelo Albe de Sespedes samo je djelimično predstavljeno čitalačkoj publici na srpskom i hrvatskom govornom području i to preko prevoda tri romana: Nessuno torna indietro, Dalla parte di lei i Quaderno proibito. Prevodi romana su izlazili u periodu od 1941. do 1980. godine, uključujući i njihova ponovna izdanja, da bi se nakon 1980. godine prestali definitivno štampati. Nema sumnje da je prestanak štampanja ovih djela, zajedno sa manjkom interesa za prevođenje ostatka opusa književnice, negativno uticao na njenu recepciju i uspjeh na tlu bivše Jugoslavije. Stoga je jasno da bi današnji čitalac srpskog i hrvatskog govornog područja koji se ne služi italijanskim jezikom, naišao na niz poteškoća u slučaju da se odluči upoznati sa stvaralaštvom Albe de Sespedes. Poteškoće se prvenstveno odnose na činjenicu da je većinu romana skoro nemoguće pronaći u prodaji (sa izuzetkom rijetkih antikvarnica), dok se neki od njih se nalaze samo u malobrojnim bibliotekama. Konkretno, kada je u pitanju srpsko i hrvatsko govorno područje, u bibliotekama je najzastupljeniji roman Dalla parte di lei jer je, kao što će se vidjeti, riječ o djelu čiji je prevod doživio nekoliko izdanja, a potom slijedi Nessuno torna indietro koji se nalazi u svega par biblioteka, dok je Quaderno proibito moguće pročitati samo u sklopu časopisa „Praktična žena“ čiji se brojevi danas teško pronalaze u bibliotekama. Osim pomenutih djela, 1984. godine jugoslovenska čitalačka publika imala je rijetku priliku sa se susretne sa prevodom pripovijetke La paura objavljene u decembarskom broju časopisa „Arianna“ 1957. godine. Ovo kratko prozno ostvarenje Albe de Sespedes, prevedeno pod naslovom Strah, se našlo u sklopu antologije Posljednji dio puta. Talijanska pripovijetka (1945-1980), priređene od strane Nedjeljka Fabrija koji je ujedno i prevodilac odabranih tekstova.

Iz nekoliko pisama Albe de Sespedes, upućenim izdavačima i prevodiocima u periodu od 1964. do 1968. godine, jasno se vidi da je ova spisateljica imala ozbiljnu namjeru da tadašnjoj čitalačkoj publici u Jugoslaviji predstavi što veći dio svoj opusa, pa je stoga u pomenutom periodu vodila pregovore u vezi sa objavljivanjem romana Il rimorso (1963) i La Bambolona (1967). Međutim, kriza u sektoru izdavaštva šezdesetih godina prošlog vijeka, prekid komunikacije sa prevodiocima i manjak interesovanja za prevođenje djela imena italijanske književne tradicije su 
neki od razloga zbog kojih su čitaoci ostali uskraćeni za prevode ne samo pojedinih romana, već i pripovijedaka i poetskih ostvarenja. Iz pisma Albe de Sespedes poslanog 10. oktobra 1964. godine Ruži Vesel (Ruža Wessel), prevoditeljki romana Dalla parte di lei, saznajemo da je zagrebačka izdavačka kuća Zora, koja je prethodno već objavila Dalla parte di lei u prevodu iz pera Veselove, odbila prijedlog za objavljivanje Il rimorso. Iz bilješki Albe de Sespedes koje je uredno vodila kako bi imala što bolji uvid u prisustvo svojih djela u inostranstvu, pod naslovom Alba de Céspedes: Il Rimorso, Trattative che hanno avuto esito negativo a koje datiraju iz 1965. godine, može se saznati da književnica, nakon negativnog ishoda saradnje sa Zorom, nije odustala od ideje da objavi svoj roman u Jugoslaviji, te je odlučila da pregovore povjeri Jugoslovenskoj autorskoj agenciji. U bilješkama se nalazi i odlomak iz kojeg se može naslutili da novosadski izdavač Bratstvo-jedinstvo, iz nepoznatih razloga, nije bio zainteresovan za objavljivanje ovog djela, uskrativši na taj način jugoslovenske čitaoce da se upoznaju sa ostvarenjem Albe de Sespedes koje pripada zreloj fazi njenog rada. Godinu dana kasnije, u pismu Miodraga Stamatovića, tadašnjeg direktora Jugoslovenske autorske agencije, navode se razlozi zbog kojih je Zora odustala od objavljivanja djela, te saznajemo da roman nije ugledao svjetlo dana zbog restrikcija koje je zagrebački izdavač uveo zbog krize na polju izdavaštva. Slična sudbina je zadesila roman La bambolona, pa stoga Alba de Sespedes ni ovaj put nije imala sreće u namjeri da ga prezentuje u Jugoslaviji ${ }^{10}$.

\section{Nessuno torna indietro}

1941. godine, tri godine nakon što je Nessuno torna indietro objavljen u Italiji kod poznatog milanskog izdavača Mondadori, njegov prevod izlazi u Zagrebu u izdanju Naklade Ante Velzek ${ }^{11}$. Treba svakako napome-

10 Nakon što je Ruža Vesel zbog zdravstvenih problema odustala od prevođenja romana i pregovora sa Zorom, Alba de Sespedes je odlučila da pregovore povjeri Jugoslovenskoj autorskoj agenciji. Ove podatke saznajemo iz pisma Albe de Sespedes upućenog Odet Arno 21. juna 1968. godine. Međutim, Jugoslovenska autorska agencija nije našla izdavača, te stoga La bambolona nije nikada preveden.

11 Ante Velzek je 1934. osnovao izdavačku kuću Binoza - svjetski pisci, koja je 1941. preimenovana u Nakladu Ante Velzek. Prije objavljivanja romana Nessuno torna indietro, 1940. godine u prevodu Josipa Tobarine Naklada Ante Velzek je izdala 
nuti da je riječ o romanu sa kojim mlada književnica stiče slavu svjetskih razmjera, te da se Nessuno torna indietro, iako nije prvo djelo napisano iz pera Alba de Sespedes, može na neki način smatrati njenim prvencem. O razlozima uspjeha svog književnog ostvarenja Alba de Sespedes progovara u više navrata, a između ostalog u već pomenutom intervjuu iz 1990. godine: „Fu soprattutto perché era una storia di donne e poi forse perché era raccontato bene; allora c'erano anche molti libri che non erano realisti. E ancora oggi si continua a vendere" (Carroli, 1993: 182). Radnja romana je smještena u ženskom internatu „Grimaldi“ u Rimu u periodu od 1934. do 1936. godine. Cenzurisan od strane fašističkog režima, Nessuno torna indietro prati sudbinu osam mladih žena, uglavnom studentica književnosti, različitih po porijeklu, društvenom statusu, ali i po karakternim osobinama. Djelo je doživjelo veliki broj izdanja u Italiji, a nakon što je njegov prvi prevod na mađarski jezik ugledao svjetlost dana već 1939. godine, slijede drugi prevodi na preko dvadeset jezika objavljeni u evropskim i vanevropskim zemljama.

Hrvatsko izdanje naslovljeno Nikome nema povratka je izašlo u dvije knjige i to u prevodu Ante Velzeka, uglednog prevodioca sa italijanskog jezika i izdavača. Prevod je propraćen kratkim predgovorom koji ima za cilj da čitaocima približi život i rad Albe de Sespedes i da ponudi osnovne informacije o samom djelu koje, kako tvrdi Velzek ,nije kao veći dio romana, koji potječu od ženske ruke, autobiografsko pripovijedanje uspomena iz djetinjstva“" (1941: I-II). Da Velzek pozitivno ocjenjuje stvaralaštvo Albe de Sespedes, ali i sam roman svjedoči sljedeći odlomak iz uvodne riječi: „Spisateljica piše čistim, skladnim, i zaista vlastitim stilom, kojim se autorica s jednim zamahom postavila u prve redove današnje mlade talijanske književnosti“" (1941: II). Kako bi još bolje predočio roman čitaocima, prevodilac nakon predgovora navodi nekoliko odlomaka iz italijanske književne kritike, objavljenih u vodećim dnevnim listovima tridesetih godina prošlog vijeka, što nam potvrđuje da se dokumentovao i dobro informisao prije nego se upustio u sam čin prevođenja.

Nema sumnje da se prevodilac književnog djela u svom radu često suočava sa nizom problema širokog spektra, ponekad teško rješivih.

D'Anuncijev roman Solus ad solam. 1942. godine ova izdavačka kuća objavljuje i poznati roman Alda Palaceskija Sorelle Materassi pod naslovom Sestre Materassi, u prevodu muzikologa Josipa Andreisa. 
Tako na primjer, za neke prevodioce najveći problem predstavlja prenošenje stilskih osobenosti djela u metatekst dok se drugi pak suočavaju sa nedoumicama koje se tiču izbora pojedinih riječi, posebno u slučaju kada za pojedine specifičnosti izvornika ne postoji adekvatnag referent u ciljnoj kulturi. Čitaoci koji su imali priliku da pročitaju Nessuno torna indietro na italijanskom jeziku mogli su uočiti da jezik i stil ovog zanimljivog štiva ne predstavljaju nesavladivu prepreku za sve one koji se odluče okušati u njegovom prevođenju. Međutim, bez obzira na ovu činjenicu, prevodilački posao je težak sam po sebi, te se stoga se i svi teoretičari slažu oko činjenice da prevoditi znači ujedno i posredovati između kultura i da prevođenje književnog djela možemo posmatrati kao izuzetno kompleksan proces koji zahtijeva niz kompetencija i znanja iz različitih oblasti. U svom djelu $M a$ nuale del traduttore poznati teoretičar prevođenja Bruno Ozimo (Bruno Osimo) podvlači ulogu i odgovornost prevodioca koga naziva „mostom“ između dva svijeta i dvije kulture (1998: 28-29). Skoro identično poimanje uloge prevodioca se može pronaći i kod Pjeranđele Dijadori (Pierangela Diadori) koja u poglavlju o kompetencijama prevodioca navodi: „Il traduttore letterario è dunque un mediatore (una sorta di «ponte») fra due testi e due culture: quella del prototesto e quella del metatesto" (2012: 131). Takođe, Umberto Eko (Umberto Eco) u svojoj čuvenoj knjizi Kazati gotovo istu stvar (Dire quasi la stessa cosa) ističe:

Već sam ranije rekao, a danas je to opšte prihvaćen stav, da se prevod ne odnosi samo na prelaz iz jednog u drugi jezik već je reč o prelasku iz jedne u drugu kulturu ili iz jedne u drugu enciklopediju. Prevodilac ne sme da se rukovodi čisto jezičkim pravilima, već mora da uzme u obzir i kulturne elemente, u najširem mogućem smislu te reči (Eko, 2011:199) ${ }^{12}$.

Kada je u pitanju Velzekov prevod romana Albe de Sespedes, može se zaključiti da je prevodilac u ovom slučaju ispunio svoj osnovni zadatak predstavivši čitaocima jedan solidan tekst vjeran originalu. Ante Velzek je bio dobar poznavalac italijanskog jezika o čemu svjedoči i podatak da je zajedno sa Ivanom Eshinom, takođe prevodiocem, ali i novinarom i leksikografom, bio tvorac hrvatsko-italijanskog rječnika. Uprkos Velzekovim kompetencijama na polju italijanskog jezika i iskustva u prevođe- 
nju, u samom prevodu Nessuno torna indietro uočava se poneki propust i nedostatak, iako u većini slučajeva nije riječ o velikim odstupanjima od originalnog teksta kao na primjer u engleskom prevodu ovog romana ${ }^{13}$. Propusti prevodioca su najbrojniji i najočitiji u prenošenju antroponima. Čini se da se Velzek u većini slučajevima opredijelio da ostavi imena $u$ originalu vodeći se pravilom hrvatskog pravopisa da se lična imena iz jezika koji se služe latinicom pišu izvorno. Međutim, već prilikom čitanja prvih stranica romana jasno se uočava se da prevodilac nije bio doslijedan u svom izboru i da se nije vodio jednim kriterijumom. Stoga u Velzekovom prevodu pored imena napisanih u originalu (Vinca, Milly, Prudenzina, Augusta, Horsch), nalazimo na veliki broj imena koja su prilagođena jeziku primaoca. Tako je ime koje je u romanu izvorno napisano Xenia postalo Ksenija, Anna je Ana, Emanuelina kćerka Stefania je Stefanija ili Štefanija, a u pokušaju da se ime Stefano što skladnije uklopi u jezik metateksta, za njega je nađen hrvatski ekvivalent Stjepan.

U nekim slučajevima prevodilac nije bio dosljedan ni u prenošenju pojedinih riječi i izraza, pa u vezi sa tim se lako uočava da se najbrojnije omaške odnose na leksiku koja se tiče univerziteta, a to su prvenstveno tesi (završni tj. diplomski rad) i laurea (diploma). Tako je rečenica „Oggi ho dato la tesi“" (de Céspedes, 1938: 22) koju izgovara Ksenija sa ciljem da obavijesti drugarice o odbrani diplomskog rada prevedena kao „Danas sam polagala predispit“ (de Céspedes, 1941a: 26), dok u drugim slučajevima riječ tesi često prevodi često kao ispit, a u nekoliko navrata i kao doktorska teza. Sa druge strane, riječ laurea je prevedena kao doktorat ili doktorski ispit, a glagol laurearsi (diplomirati) je preveden kao položiti ispit. U italijanski univerzitetski sistem obrazovanja doktorat je uveden tek 1980. godine, tako da se prevod riječi tesi i laurea može definitivno sma-

13 U prevodu na engleski jezik Jan Noubl (Jan Noble) objavljenom 1940. godine u Velikoj Britaniji pod naslovom There's no turning back uočavaju se ozbiljniji propusti. Tako na primjer u rečenici „Una suora, accorsa con l'aceto e le pezze, aveva capito che tutto era inutile [...]“ (de Céspedes, 1938: 111) riječ pezze (krpe) je iz nepoznatih razloga prevedena kao silver coins (de Céspedes, 1940: 102). U rečenici: „Sai che [Horsch] tiene la moglie e la figlia a Menaggio in una casa modestissima, facendo credere loro che lui, a Milano, si arrabatta per guadagnare“ (de Céspedes 1938: 171), una casa modestissima (preskromna kuća) iz nepoznatog razloga postaje a most elegant house (de Céspedes, 1940: 153). Više detalja o prevodima Albe de Sespedes na engleski jezik se može pronaći $\mathrm{u}$ radu Sandre Karleti Le traduzioni angloamericane. 
trati jednim od najvećih propusta prevodioca. Još jedan propust u vezi sa unverzitetskom terminologijom odnosi na momenat u knjizi kada Andrea svojoj djevojci Emanueli saopštava rezultat na jednom od posljednjih ispita koje je polagao: „Benone, Nuela, trenta.“ (de Céspedes, 1938: 142). U ovom slučaju prevodilac ne samo da ne uspijeva naći odgovarajući ekvivalent na jeziku prevoda birajući sljedeće rješenje „Dobro je, Nuelo, prošao sam. “ (de Céspedes, 1941: 141), već lišava čitaoca podatka o sistemu ocjenjivanja u Italiji koji se kako tridesetih godina prošlog vijeka tako i danas razlikovao od sistema ocjenjivanja na hrvatskom području. Iako je ocjena trenta (trideset) u italijanskom sistemu ocjenjivanja izuzetno visoka i slijedi odmah iza najviše ocjene 30 e lode (30 sa pohvalom), iz prevoda se stiče utisak da je Andrea dobio znatno nižu ocjenu.

\section{Dalla parte di lei}

U romanu Dalla parte di lei, objavljenom 1949. godine, pripovijedanje u prvom licu je povjereno glavnoj junakinji Alesandri, koja, čekajući u zatvoru definitvnu sudsku odluku, detaljno upoznaje čitaoca sa svojim životom i obrazlaže motive koji su prethodili ubistvu njenog supruga Frančeska. Radnja romana, podijeljenog u tri cjeline, odvija se u Rimu i Abrucu za vrijeme fašizma i Drugog svjetskog rata. Dalla parte di lei, preveden u 14 zemalja, po prvi put je predstavljen jugoslovenskoj čitalačkoj publici 1960. godine i to u prevodu iz pera Ruže Vesel i Ante Rojnića, iskusnih prevodioca i dobrih poznavaoca italijanskog jezika koji su konstantno bili u dodiru sa italijanskom kulturom ${ }^{14}$. Nakon objavljivanja 1960. godine kod zagrebačke Zore pod naslovom Na njenoj strani, isti izdavač je ponovo štampao prevod 1961. i 1965. godine, dok je 1980. godine pomenuti prevod romana izašao u sklopu izdanja Grafičkog zavoda Hrvatske. Osim samog prevoda, u knjizi se nalazi i pogovor Ante Rojnića u kom autor opisuje književni put Albe de Sespedes, a potom se dotiče ključnih tema stvaralaštva ove autorke, koja je romanom Dalla parte di lei „dala stranice izvanredno žive i sugestivne proze“ (1965: 588), da bi na samom kraju

14 Ante Rojnić je pored jugoslovenske književnosti diplomirao i italijanski jezik, te je još kao gimazijalac sarađivao sa tršćanskim časopisom „Naš glas“. Sa italijanskog jezika je preveo nekoliko romana. Ruža Vesel, takođe novinarka i prevoditeljka, je živjela duže vrijeme u Italiji i to u više navrata. 
teksta ponudio kratku analizu romana čijim prevodom, kako piše Rojnić, „dobivaju naši čitaoci sada još jedno djelo suvremene talijanske spisateljice velike popularnosti - osobito među ženskim svijetom - ne samo u njenoj domovini Italiji, nego i u brojnim zemljama Evrope i ostaloga svijeta“" (1965: 583).

Na sve izazove i poteškoće sa kojima se prevodilac nerijetko susreće dok prevodi književno djelo, u slučaju Dalla parte di lei nadovezuje se i problem koji se odnosi na dužinu ovog romana. Naime, riječ je o djelu koje ima preko 500 stranica i koji je, kako je već pomenuto, zbog svoje dužine bio objavljivan u skraćenoj verziji u prevodima na druge jezike. Očito je da u ovom slučaju obim nije prevodiocima predstavljao barijeru jer su se Veselova i Rojnić opredijelili da jugoslovenskoj čitalačkoj publici predstave integralnu verziju romana. Na osnovu detaljnijeg uvida, može se zaključiti da rezultat prevodilačkog rada Veselove i Rojnića zaslužuje veoma visoku ocjenu: riječ je o prevodu koji, osim što vjerno prenosi jezik originala, uspijeva da dočara i pripovijedački stil književnice, jer jedan od primarnih zadataka prevodioca je i da, osim što korektno prevede djelo, predstavi autora onako kako mu dolikuje, prenijevši što vjernije njegov stil. Prevod Dalla parte di lei se definitivno može smatrati najboljim i najuspjelijim postojećim prevodom Albe de Sespedes na srpskom i hrvatskom govornom području. Da se radi o prevodu koji je dostojan svake pohvale, jasno je i iz dva pisma Albe de Sespedes upućenim prevoditeljki Ruži Vesel. U prvom pismu iz 10. oktobra 1964. godine, napisanom uoči objavljivanja trećeg izdanja Dalla parte di lei kod izdavačke kuće Zora, italijanska književnica koja je, kako je već u više navrata rečeno, revnosno pratila izdanja svojih romana u inostranstvu, ne krije entuzijazam i svoju zahvalnost prevoditeljki, dok u drugom pismu, koje datira iz 14. aprila 1966. godine, naglašava da je za uspjeh ovog romana u Jugoslaviji osim autora podjednako zaslužan i njegov prevodilac.

Stoga se analiziranje jednog ovakvog prevoda ne može nikako svesti na traganje za odstupanjima od originala, ali može biti prilika da se ukratko razmotre neka prevodilačka rješenja i postupci počevši od samog naslova. Naime, u velikom broju slučajeva naslov često otvara pitanje izbora prilikom njegovog prevoda na jezik primaoca. Uostalom, kako navodi Pjeranđela Dijadori: "La traduzione del titolo di un'opera (romanzo, poesia, film, quadro, brano musicale o quant'altro) ha un ruolo cruciale nel destino 
commericiale dell'opera stessa, trattandosi del „,biglietto da visita“ con cui questa si presenta al pubblico“" (Diadori, 2018: 304). Naslov Dalla parte di lei koji Alba de Sespedes odabira za svoj roman je simboličan i kao što Ante Rojnić ističe u pogovoru: „Autorica je, razumije se, potpuno na njenog strani. Ona se i u naslovu s njom [Alesandrom] idetificira, govori u njeno ime, optužuje“ (1965: 586). Vodeći se tom idejom Veselova i Rojnić su odlučili da odaberu naslov koji po njima u potpunosti reflektuje autorkinu ideju opredjelivši se da Dalla parte di lei prevedu kao Na njenoj strani, dok su prevodioci na druge jezike pribjegli potpuno drugačijim rješenjima. Tako Dalla parte di lei postaje The best of husbands u prevodu na engleski jezik, Alexandra je naslov prevoda na njemački jezik, Elles na francuski, dok se naslov El mejor de los esposos našao na koricama španskog izdanja romana. Razlog ovakvih odabira se može opravdati pokušajem se izbjegne poruka koju nosi naslov, te da se na neki način prikrije autorkino poistovjećivanje sa junakinjom Alesandrom.

Jedan od najzanimljivijih aspekata prilikom analize prevoda književnog djela jeste zasigurno prenošenje elemenata kulture sa jezika izvornika na jezik primaoca. S obzirom na to da je, kao što smo već naglasili, prevođenje i kulturološki transfer, često se nameće pitanje na koji način prenijeti elemente jedne kulture u drugu, te kako približiti čitaocu teže prevodive kulturne koncepte: da li zadržati strane riječi iz originala u prevodu i orijentisati se ka izvornoj kulturi, pribjegavajući na taj način strategiji forenizacije (foreignization), ili se opredijeliti za suprotnu strategiju poznatu kao domestikaciju (domestication) odnosno prilagoditi izvorni jezik i kulturu ciljnom jeziku i kulturi. Jedan od prvih teoretičara koji se dovodi u vezu sa pomenutim strategijama je njemački teolog i filozof Fridrih Šlajermaher (Friedrich Schleiermacher). U svom djelu Über die verschiedenen Methoden des Übersetzens iz 1813. godine Šlajermaher uzima u obzir dvije moguće opcije u procesu prevođenja: ili udaljavanje od pisca i primicanje čitaocu ili pak primicanje piscu a odmicanje od čitaoca, upozoravajući pritom da je od ključnog značaja ne pribjegavati miješanju ova dva pristupa. Ovim složenim pitanjem se, ozmeđu ostalog, detaljnije pozabavio i američki teoretičar Lorens Venuti (Lawrence Venuti) u svom djelu The Translator's Invisibility. A History of Translation (1995). Naslanjajući se na Šlajermaherove stavove, Venuti se jasno opredjeljuje za strategiju forenizacije: ,[...] an ethnodeviant pressure on those values to register the 
linguistic and cultural difference of the foreign text, sending the reader abroad" (1995: 20).

$\mathrm{S}$ obzirom na to da u nauci o prevođenju ne postoji jedinstven stav $\mathrm{u}$ vezi sa ovom dilemom, prevođenje kulturoloških koncepata i njihovo približavanje čitaocu zavisi od odabira prevodioca ali i od niza drugih faktora. Kada je u pitanju prevod romana Dalla parte di lei, jasno se uočava da su se prevodioci trudili da ne liše čitaoca potpunog doživljala Rima i života u Italiji početkom četrdesetih godina prošlog vijeka, težeći da u više navrata zadrže u prevodu specifičnosti koji prenose lokalnu boju izvornika i tradicije iz koje potiču. Zbog toga su se opredijelili da većinu toponima ostave $\mathrm{u}$ originalu kako bi čitalac sve vrijeme imao utisak da se radnja odvija u Rimu (Villa Borghese, Appia Antica, Lungotevere, Via Nazionale) ili pak da u samom tekstu uz transkripciju zadrže neke italijanske riječi iz domena kulture i društva (konfeti, otočento, kvestura, skopa). U pojedinim slučajevima prevodioci su koristili strategiju upotrebe pozajmljenica, odnosno, nisu prevodili određene termine u samom tekstu, već u fusnoti. Sa tim u vezi riječ Ottocento u rečenici „Disse che sembravi uscita da un quadro dell'Ottocento“ (de Céspedes, 1976: 578) je u prevodu prenešena kao otočento - „Rekao ti je, da izgledaš kao da si izašla s neke slike iz otočenta“ (de Céspedes, 1965a: 302), dok se u fusnoti nalazi prevod: „Ottocento devetnaesto stoljeće“ (de Céspedes, 1965a: 302). Isto tako, prevodici riječ questura rečenici „Papà è stato in questura“ (de Céspedes,1976: 374) nisu preveli, već je samo transkribovali kao kvestura uz objašnjenje u fusnoti da je riječ o direkciji policije (de Céspedes, 1965a: 76). Poneka fusnota je takođe predviđena za pojašnjenje manje poznatih kulturoloških pojmova, imena ličnosti iz italijanske istorije i kulturnog života ili čuvenih lokacija grada Rima. Tako, na primjer, prevodioci pojašnjavaju da je Salvatore di Giacomo „napuljski pjesnik, koji piše stihove u lokalnom narječuju“ (de Céspedes, 1965a: 290), Me ne vogli'i' a Surriento - ,poznata pjesma u napuljskom dijalektu“ (de Céspedes, 1965a: 160), confino - ,izgnanstvo, prisilni boravak, redovito na osamljenim otocima (npr. Lipari), kamo je fašistički režim slao svoje protivnike“" (de Céspedes, 1965a: 442), te Mantellate - ,poznati zatvor za žene u Rimu“ (de Céspedes, 1965a:). Odabir Veselova i Rojnić da u nekoliko navrata proprate pojedine izraze dodatnim bilješkama u vidu fusnota kako bi primaoca prevoda opskrbili neophodnim informacijama o značenjima pojmova koja im civilizacijski nisu bili 
bliski i na taj način mu olakšali kretanje društveno-istorijskim kontekstom romana opravdan je činjenicom da kulturna predznanja čitalaca nije uvijek lako predvidjeti, posebno kada se radi o heterogenoj grupi, te se bazira na subjektivnoj procjeni da bi prosječan čitalac bivše Jugoslavije šezdesetih godina prošlog vijeka imao poteškoća da razumije određene termine usko vezane za italijansku društveno-kulturnu stvarnost.

\section{Quaderno proibito}

Godine 1952. Alba de Sespedes, uveliko afirmisanja književnica i novinarka, objavljuje treće veliko djelo - Quaderno proibito. Napisan u formi dnevnika, kroz priču o glavnoj junakinji Valeriji, roman tematizuje položaj žene u italijanskom društvu i njenu ulogu u krilu porodice na početku pedesetih godina prošlog vijeka. Poseban akcenat u romanu je na činu pisanja - temi kojom se književnica bavila sa naročitom pažnjom već od Nessuno torna indietro.

Quaderno proibito, preveden u 19 zemalja, odmah poslije Nessuno torna indietro je najprevođenije djelo Albe de Sespedes. Međutim, roman na srpskom i hrvatskom govornom području nije imao podjednak uspjeh kao i ostatku svijeta, te je stoga i čitalačka publika bivše Jugoslavije ostala uskraćena za njegov integralan prevod. Naime, skraćena verzija romana pod naslovom Zabranjena sveska u prevodu anonimnog prevodioca objavljena je u aprilu 1959. godine na stranicama „Zelenog dodatka“ časopisa „Praktična žena“. Kako se navodi u doktorskoj disertaciji Nede Todorović Uzelac „Ženska “ štampa i emancipacija žena (analiza sadržaja visokotiražnih ,,̌̌enskih “ listova u Jugoslaviji u posleratnom periodu), ovaj časopis, pokrenut 1956. godine u izdanju beogradske Duge, od samog početka se obraćao čitateljkama iz najširih slojeva, a zajedno sa Bazarom, Svijetom, Unom i Nadom se svrstava u kategoriju visokotiražnih časopisa. „Uočljiva karakteristika ovih listova je spora evolucija njihovog sadržaja sa obeležjem nepromenjivosti i međusobne sličnosti“" (1985: 211), te stoga svi u strukturi sadržaja imaju zajedničke elemente među kojima je i sentimentalna pseudoliteratura zbog koje je ova štampa i nazvana ,štampom srca (romani u nastavcima, feljtoni o ljubavima poznatih žena, intimne ispovesti čitateljki)“(1985: 212). Pored romana i novela, prožetih najčešće ljubavnom tematikom, koji su uglavnom izlazili u nastavcima u okviru samog časopisa, uz „Praktičnu ženu“ je u vremenskom periodu od 1959. do 1972. godine izlazio i ,Zeleni dodatak“ na či- 
jih pedesetak stranica bi se našle često skraćene verzije romana među kojima prednjače djela prevedena sa engleskog i francuskog jezika ${ }^{15}$, često upitnog književnog kvaliteta i prilagođena ukusu široke publike.

Da je Alba de Sespedes imala namjeru da predstavi svoj treći veliki roman jugoslovenskim čitaocima preveden u cjelini i u potpuno drugačijem kontekstu, svjedoče i odlomci iz njene prepiske sa prevodiocima i izdavačima. U pismu napisanom Ruži Vesel 16. februara 1968. godine, italijanska književnica se informiše o mogućnosti objavljivanja romana koji je prethodno odbijen od strane izdavačke kuće Zora, pitajući se pritom kako je moguće da je Jugoslavija na spisku rijetkih zemalja u kojima ovo djelo nije prevedeno. Iz nepoznatih razloga, odgovor se ne može pronaći ni u jednom pismu Veselove. Podatak o prevodu Quaderno proibito u sklopu pomenutog časopisa je prevoditeljki bio zasigurno poznat s obzirom na činjenicu da se našao u vidu fusnote na prvoj stranici Rojnićevog pogovora prevodu romana Dalla parte di lei. Pregovori u vezi sa prevodom romana Quaderno proibito se nastavljaju do 1970. godine, kada spisateljica, nakon prekida kontakta i saradnje sa Ružom Vesel, odlučuje da se obrati Božidaru Markoviću iz Jugoslovenske autorske agencije. Iz pisma upućenog Albi de Sespedes 1970. godine, saznajemo da je Marković roman Quaderno proibito poslao na čitanje čuvenoj prevoditeljki Jugani Stojanović16. Nažalost, iz nepoznatih razloga, roman nikada nije objavljen u prevodu Stojanovićeve, a stoga ni čitaoci nisu imali mogućnost da se upoznaju sa integralnim prevodom ovog značajnog djela ${ }^{17}$. Po svemu sudeći, jugoslo-

15 Na stranicama „Zelenog dodatka“ su se našli, između ostalog, roman Rebeka (Rebecca, 1938) i Duh ljubavi (The Loving Spirit, 1931) čuvene autorke ljubavnih romana Dafne di Morije (Daphne du Maurier), Ljubav i novac (Love and Money, 1954) američkog književnika Erskina Koldvela (Erskine Caldwell) i Jedna noć ljubavi (Une nuit d'amour, 1931) danske autorke Karen Bramson.

16 Riječ je o prevoditeljki koja je odigrala značajnu ulogu u prevođenju italijanskih autora poput Pavezea, Moravije i Pazolinija. O njenom zalaganju i radu svjedoče i nagrade koje su joj dodijeljene 1987. godine (nagrada „Miloš Đurić“ za prevod Bucatijevog romana Un amore) i 2007. godine (priznanje za vrhunski doprinos nacionalnoj kulturi u republici Srbiji).

17 Iz telefonskog razgovora sa Juganom Stojanović, obavljenom u februaru 2016. godine, saznali smo da prevoditeljka nije imala priliku da se blisko susretne sa radom Albe de Sespedes. Stoga, najvjerovatnije, roman Quaderno proibito nikada nije došao do nje. 
PREVODI ROMANA ALBE DE SESPEDES NA SRPSKOM I HRVATSKOM ...

venski prevod trećeg velikog romana Albe de Sespedes je neautorizovan s obzirom na to da je realizovan bez znanja Albe de Sespedes, izdavačke kuće Mondadori i Jugoslovenske autorske agencije preko koje su se u to vrijeme dobijala autorska prava.

Kada je u pitanju sam prevod romana, osim činjenice da se ne radi o integralnoj verziji, njegov najveći nedostatak se odnosi na podatak da je riječ o prevodu sa jezika posrednika - u ovom slučaju francuskog. Roman je pod naslovom Le cahier interdit u Francuskoj objavljen 1954. godine od strane pariškog izavača Seuil i to u prevodu Žulijet Bertran (Juliette Bertrand), koja je takođe zaslužna za francuske prevode prethodna dva romana Albe de Sespedes. Prevod iz pera Bertranove je doživio nekoliko izdanja, te je objavljivan u kontinuitetu do 1981. godine, kako kod istog izdavača, tako i pod okriljem drugih izdavačkih kuća. Pored toga, 1957. godine u časopisu „Le Petit Echo de la Mode“, kompletan roman Le cahier interdit $\mathrm{u}$ prevodu Žulijet Bertran objavljivan je u nastavcima u periodu od 9. juna do 4. avgusta 1957. godine. Sasvim je jasno da je anonimni prevodilac sačinio svoj prevod romana Quaderno proibito na srpski jezik prema prevodu Bertranove, bilo da se koristio izdanjem iz 1954. godine ili pak prevodom objavljenom u pomenutom časopisu. Da se radi o posrednom prevodu, između ostalog, jasno upućuje i transkripcija ličnih imena predočena u tabeli 1 .

\begin{tabular}{|c|c|c|c|}
\hline $\begin{array}{c}\text { Imena u } \\
\text { originalnom } \\
\text { tekstu }\end{array}$ & $\begin{array}{c}\text { Imena u } \\
\text { francuskom } \\
\text { prevodu }\end{array}$ & $\begin{array}{c}\text { Imena u } \\
\text { prevodu } \\
\text { na srpski jezik }\end{array}$ & $\begin{array}{c}\text { Pravilna transkripcija } \\
\text { sa italijanskog na } \\
\text { srpski jezik }\end{array}$ \\
\hline Valeria & Valérie & Valerija/Valeri & Valerija \\
\hline Michele & Michel & Mišele & Mikele \\
\hline Mirella & Mireille & Mirej & Mirela \\
\hline Riccardo & Richard & Rišar & Rikardo \\
\hline Clara & Claire & Kler & Klara \\
\hline Giuliana & Julienne & Žilijena & Kamilana \\
\hline Camilla & Camille & Kamij & \\
\hline
\end{tabular}

Tabela 1: Transkripcija ličnih imena u prevodu romana Quaderno proibito

Iako posredni prevodi često igraju značajnu ulogu u književnoj i kulturnoj razmjeni i uspostavljanju kontakata između jezičkih zajednica, oni 
se smatraju manje adekvatnima zbog činjenice da ovakvav vid prevođenja nerijetko karakterišu brojna pomjeranja usljed kojih dolazi do udaljavanja kako od jezika, tako i od kulture izvornika. U navedenom primjeru zadržavanje specifičnosti koje prenose lokalnu boju izvornika, u ovom slučaju antroponima, zasigurno bi doprinijelo kvalitetu prevoda i omogućilo da čitalac ne bude lišen doživljalja italijanske realnosti s obzirom na činjenicu da se francuska prevoditeljka nije opredijelila za originalnu varijantu ličnih imena već za francuske ekvivalente koji su prilikom posrednog prevodjenja dosljedno prenijeti na srpski jezik.

\section{Romani Albe de Sespedes u novom ruhu}

Nakon kratkog uvida u postojeće prevode djela Albe de Sespedes na srpskom i na hrvatskom govornom području, evidentno je da se u većini slučajeva nameće potreba za njihovom retradukcijom ${ }^{18}$. Na uvodnim stranicama četvrtog broja časopisa Palimpsestes iz 1990. godine posvećenom u potpunosti retradukciji, Pol Bensimon (Paul Bensimon) naglašava: „Comme traduire, retraduire est à la fois un acte individuel et une pratique culturelle“ (1990: IX). Postojanje dva ili čak više prevoda istog književnog djela nesumnjivo je stimulativan korpus za analiziranje i osvjetljavanje različitih prevodilačkih tehnika i postupaka. Uostalom, zrelost jedne prevodilačke kulture ne ogleda se samo u broju prevedenih djela već i u prisustvu više prevoda istog književnog djela. Upravo zbog toga, mnogi su razlozi zbog kojih se jedno književno djelo treba pojaviti u novom ruhu, ali zasigurno ključni motiv ove operacije treba tražiti u zastarijevanju jezika i prilagođavanju novog prevoda modernom čitaocu. S tim u vezi, u četvrtom broju časopisa Palimpsestes iz 1990. godine Antoan Berman (Antoine Berman) zastupa mišljenje da je većina prevoda podložna ,zastarjevanju“ dok su, sa druge strane, književna djela ta koja ostaju vječno „mlada“: „alors que les originaux restent éternellement jeunes (quel que soit le degré d'intérêt que nous leur portons, leur proximité ou leur éloignement cultu-

18 Iako pojam retradukcija ponekad može da ukaže i na prevod sa jezika posrednika, kao što se navodi u Dictionary of Translation Studies pod odrednicom „retlanslation“ (Shuttleworth, Cowie, 1997: 76-77), Ana Jovanović podvlači da se ovaj termin danas ustalio u značenju koje je precizirao Berman: ,reč je o novom prevodu dela čiji su jedan ili više prevoda na isti ciljni jezik već objavljeni; retradukcija je neka vrsta reaktuelizovanja izvornog teksta“" (2012:167-168). 
rel), les traductions, elles, «vieillissent»" (1990: 1). Vanda Mikšić ističe da je jedna od temeljnih karakteristika prevoda koja ga razlikuje od književnog djela „njegova serijalnost, ponovljivost, mogućnost, dakle, da se isti tekst prevede više puta“" (2011: 119).

$\mathrm{S}$ tim u vezi, prvi korak bi nesumnjivo trebalo da bude integralni prevod romana Quaderno proibito. Iako je predstavljen čitalačkoj publici u cjelosti, roman Nessuno torna indietro takođe bi trebalo da se pojavi preveden u novom ruhu jer, zbog arhaičnog jezika, postojeći prevod nije najadekvatniji za današnjeg čitaoca. Razloge retradukcije treba tražiti i u činjenici da je riječ o djelu koje doživjelo veliki broj stilističkih i jezičkih korekcija, te nekoliko značajnih izmjena koje se tiču društveno-istorijskog konteksta. 1966. godine u ediciji Narratori italiani izdavačke kuće Mondadori izlazi posljednja izmijenjena verzija romana po kojoj bi zasigurno trebalo sačiniti novi prevod ${ }^{19}$. Kada su u pitanju prevodi koji nisu ugledali svjetlost dana, prevodioci bi trebalo svakako da uzmu u obzir ve

pomenute Il rimorso i La bambolona, kratki roman Prima e dopo (1955), djelo koje zatvara jednu fazu stvaralaštva Albe de Sespedes i otpočinje novu, na što i aludira i njegov naslov, te Con gran amor, posljednji, nedovršeni roman, posvećen voljenoj Kubi. Nadamo se da će budući prevodioci imati u vidu i zbirke pripovijedaka, poeziju, te novinske članke i tekstove sa društveno-političkom pozadinom koji svakako zauzimaju značajno mjesto u plodnom stvaralaštvu Albe de Sespedes.

19 Ako se uporedi prvo izdanje romana iz 1938. sa posljednjim iz 1966. godine, uočava se da je spisateljica izvršila veliki broj izmjena, prevashodno jezičke i stilističke prirode - jasan pokazatelj njenog književnog sazrijevanja. Međutim, ne treba zanemariti činjenicu da nova verzija romana svjedoči o promjenama koje se tiču društveno-istorijskog konteksta: u izdanju iz 1966. nedostaju mnoge pojedinosti koje se mogu direktno dovesti u vezu sa presijama i uticajem fašističkog režima. 


\section{LITERATURA}

a) Primarna literaura

De Céspedes, A. (1938). Nessuno torna indietro. Milano: Mondadori.

De Céspedes, A. (1940). There's No Turning Back. Translation of Jan Noble. London: Jarrolds.

De Céspedes, A. (1941a). Nikome nema povratka, I dio. Preveo A. Velzek. Zagreb: Nakladni zavod Ante Velzek.

De Céspedes, A. (1941b). Nikome nema povratka, II dio. Preveo A. Velzek. Zagreb: Nakladni zavod Ante Velzek.

De Céspedes, A. (9 juin 1957 - 4 août 1957). Le Cahier interdit, Le Petit Écho de la mode.

De Céspedes, A. (april 1959). Zabranjena sveska. Praktična žena. Zeleni dodatak.

De Céspedes, A. (1963). Quaderno proibito. Milano: Mondadori.

De Céspedes, A. (1965a). Na njenoj strani. Preveli R. Wessel i A. Rojnić. Zagreb: Zora.

De Céspedes, A. (1965b). Le Cahier interdit. Traduit de l'italien par J. Bertrand. Paris: Le Club de la femme.

De Céspedes, A. (1976). Dalla parte di lei. Milano: Mondadori.

De Céspedes, A. (1984). Strah. U N. Fabrio (izbor, prevod i komentar) Poslednji dio puta 1. Talijanska propovijetka 1945-1980 (177-186). Zagreb: GZH.

De Céspedes, A. (2011). Romanzi. A cura di e con un saggio introduttivo di M. Zancan. Milano: Mondadori.

b) Sekundarna literatura

Bensimon, P. (1990). Présentation. Palimpsestes. Revue de traduction, 4, IX-XIII.

Berman, A. (1990). La retraduction comme espace de la traduction. Palimpsestes. Revue de traduction, 4, 1-7.

Carletti, S. (2005). Le traduzioni angloamericane. In M. Zancan (a cura di), Alba de Céspedes. Scrittrici e intellettuali del Novecento (pp. 415-418). Milano:

Il Saggiatore/Fondazione Arnoldo e Alberto Mondadori.

Carroli, P. (1993). Esperienza e narrazione nella scrittura di Alba de Céspedes. Ravenna: Longo Editore.

Diadori, P. (2012). Teoria e tecnica della traduzione. Strategie, testi e contesti. Milano: Mondadori Education.

Diadori, P. (2018). Tradurre: una prospettiva interculturale. Roma: Carocci. 
Di Nicola, L. (2013). Il canone inverso. I classici italiani del Novecento all'estero. In L. Di Nicola e C. Schwartz (a cura di). Libri in viaggio. Classici italiani in Svezia (pp. 64-88). Stoccolma: Acta Universitatis Stockholmiensis.

Eko, U. (20110). Kazati gotovo istu stvar. Preveli Mirela Radosavljević i Aleksandar Levi. Beograd: Paideia.

Jovanović, A. (2012). Hipoteza o retradukciji pod lupom istraživača. Riječ, 8, 167-193.

Mikšić, V. (2011). Interpretacija i prijevod. Zagreb: Meandarmedia.

Osimo, B. (1998). Manuale del traduttore. Milano: Hoepli editore.

Rojnić, A. (1965). Alba de Céspedes. Uz prijevod romana „Na njenoj strani“. U A. de Céspedes, Na njenoj strani. Preveli R. Wessel i A. Rojnić (str. 583589). Zagreb: Zora.

Schleiermacher, F. (2003). O različitim metodima prevođenja. Beograd: Rad.

Shuttleworth, M. \& Cowie, M. (1997). Dictionary of Translation Studies. London/New York: Routledge.

Todorović Uzelac, N. (1985). „Ženska“ štampa i emancipacija žena (analiza sadržaja visokotiražnih ,ženskih “ listova u Jugoslaviji u posleratnom perio$d u$ ) (neobjavljen doktorski rad). Fakultet političkih nauka, Beograd.

Velzek, A. (1941). Alba de Céspedes. U A. de Céspedes, Nikome nema povratka, I dio. Preveo A. Velzek (str. I-II). Zagreb: Nakladni zavod Ante Velzek.

Venuti, L. (1995). The Translator's Invisibility. A History of Translation. London/ New York: Routledge.

Zancan, M. (a cura di). (2001). Scrittrici e intellettuali del Novecento. 2. Alba de Céspedes. Milano: Fondazione Arnoldo e Alberto Mondadori.

Zancan, M. (a cura di). (2005). Alba de Céspedes. Milano: Fondazione Arnoldo e Alberto Mondadori. 


\section{Zorana Ž. Kovačević}

\section{LE TRADUZIONI DEI ROMANZI DI ALBA DE CÉSPEDES NELL'AMBITO SERBO E CROATO}

\section{Riassunto}

Il presente contributo intende fornire un quadro delle traduzioni in ambito serbo e croato dei romanzi di Alba de Céspedes, scrittrice, giornalista e intellettuale italo-cubana. Tradotta in 29 paesi europei ed extraeuropei, in modo continuativo soprattutto dal 1939 al 1985 grazie all'interessamento diretto e al grande lavoro di pubbliche relazioni della stessa autrice, l'opera di Alba de Céspedes è stata introdotta nei paesi di lingua croata e serba con la traduzione integrale di due romanzi Nessuno torna indietro nel 1941 e Dalla parte di lei nel 1960 e con la traduzione parziale del romanzo Quaderno proibito nel 1959. La difficile reperibilità di queste traduzioni e la mancanza di ristampe hanno sicuramente influenzato in modo negativo la ricezione della scrittrice in area balcanica. Inoltre, ci si soffermerà brevemente anche sulla corrispondenza con gli editori e i traduttori dell'ex Jugoslavia; e si rifletterà sull'utilità di riproporre i tre romanzi in nuove traduzioni, ma anche sull'opportunità di tradurre altre opere del vasto corpus della produzione dell'autrice che spazia dalla narrativa e dalla poesia al giornalismo, al cinema, al teatro.

Parole chiave: Alba de Céspedes, letteratura italiana del Novecento, $\mathrm{Ne}$ ssuno torna indietro, Dalla parte di lei, Quaderno proibito, traduzione 